\title{
Article \\ Impact of Palonosetron on Cough Suppression in Females Undergoing Sevoflurane-Remifentanil Anesthesia for Laparoscopic Cholecystectomy: A Randomized Trial
}

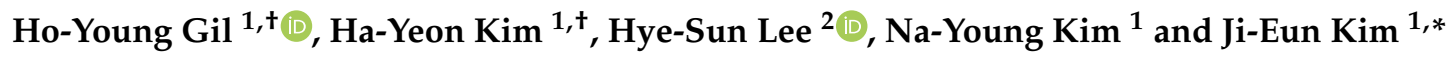 \\ 1 Department of Anesthesiology and Pain Medicine, Ajou University School of Medicine, 164, World Cup-ro, \\ Yeongtong-gu, Suwon 16499, Korea; kilhoyoung@naver.com (H.-Y.G.); hayeon@aumc.ac.kr (H.-Y.K.); \\ jhkyanb@gmail.com (N.-Y.K.) \\ 2 Biostatistics Collaboration Unit, Yonsei University College of Medicine, Seoul 03722, Korea; HSLEE1@yuhs.ac \\ * Correspondence: beye98@aumc.ac.kr; Tel.: +82-31-219-5575 \\ + These authors contributed equally to this project.
}

check for updates

Citation: Gil, H.-Y.; Kim, H.-Y.; Lee, H.-S.; Kim, N.-Y.; Kim, J.-E. Impact of Palonosetron on Cough Suppression in Females Undergoing SevofluraneRemifentanil Anesthesia for Laparoscopic Cholecystectomy: A Randomized Trial. J. Pers. Med. 2021, 11, 887. https://doi.org/10.3390/ jpm11090887

Academic Editor: Marco Milone

Received: 10 August 2021

Accepted: 2 September 2021

Published: 5 September 2021

Publisher's Note: MDPI stays neutral with regard to jurisdictional claims in published maps and institutional affiliations.

Copyright: (c) 2021 by the authors. Licensee MDPI, Basel, Switzerland. This article is an open access article distributed under the terms and conditions of the Creative Commons Attribution (CC BY) license (https:/ / creativecommons.org/licenses/by/ $4.0 /)$.

\begin{abstract}
Remifentanil has been used to suppress peri-extubation cough. Palonosetron, a 5- $\mathrm{HT}_{3}$ receptor antagonist, is an effective antiemetic, and 5-HT receptors mediate the cough reflex. We assessed the impact of palonosetron on effect-site concentration (Ce) of remifentanil for preventing emergence cough in females. Forty-five female patients undergoing laparoscopic cholecystectomy randomly received $0.075 \mathrm{mg}$ of palonosetron $(n=21)$ or normal saline $(n=24)$ intravenously at the end of surgery. The remifentanil Ce for $50 \%\left(\mathrm{EC}_{50}\right)$ and for $95 \%\left(\mathrm{EC}_{95}\right)$ of patients were estimated via Dixon's up-and-down method or isotonic regression. Using Dixon's method, $\mathrm{EC}_{50}$ in the control group $(1.33 \pm 0.38 \mathrm{ng} / \mathrm{mL})$ was comparable to that of the palonosetron group $(1.42 \pm 0.75 \mathrm{ng} / \mathrm{mL})(p=0.813)$. Using isotonic regression, $\mathrm{EC}_{50}(83 \% \mathrm{CIs})$ and $\mathrm{EC}_{95}(95 \% \mathrm{CIs}) \mathrm{did}$ not reveal significant differences between the control and the palonosetron groups $(1.17(0.86-1.43)$ and $1.90(1.45-1.96) \mathrm{ng} / \mathrm{mL}$ and $0.88(0.78-1.23)$ and 2.43 (1.94-2.47) $\mathrm{ng} / \mathrm{mL}$, respectively). No difference was found in the remifentanil Ce to suppress emergence cough in the palonosetron group compared with the control group. It may indicate no effect of palonosetron on antitussive activity of remifentanil.
\end{abstract}

Keywords: emergence cough; female; palonosetron; remifentanil

\section{Introduction}

Cough during emergence from general anesthesia frequently occurs in intubated patients, with an incidence as high as $76 \%$ [1]. Tracheal stimuli from the endotracheal tube are perceived by the central and peripheral nervous system, producing the cough [2]. Cough serves a protective role in facilitating the clearance of an inhalation agent, secretions, and irritants. However, the peri-extubation cough may adversely affect patients undergoing surgery, due to complications, such as hematoma of surgical site, wound dehiscence, and increased intracerebral and intraocular pressures [3,4]. Therefore, various interventions have been tried to minimize cough for a smooth emergence [5-7].

Remifentanil is a potent ultrashort-acting opioid accompanied by rapid onset and offset of effect. The target-controlled infusion (TCI) of remifentanil enables smooth extubation alongside lowered complications [8]. In a meta-analysis of 70 studies, remifentanil was the most effective in decreasing the severe peri-extubation cough compared with fentanyl, dexmedetomidine, and lidocaine [9]. Further, it attenuated the increase in hemodynamic parameters without extending the extubation time [9].

Postoperative nausea and vomiting (PONV) is a common adverse effect of anesthesia and surgery. PONV is associated with patient dissatisfaction, prolonged hospital stay, and higher costs of care in addition to severe complications [10]. Palonosetron is a popular 
antiemetic used for PONV prevention with long-lasting efficacy due to greater binding affinity to the 5-hydroxytryptamine-3 $\left(5-\mathrm{HT}_{3}\right)$ receptor [11]. In addition, palonosetron was more effective than ramosetron in preventing PONV during laparoscopic cholecystectomy [12].

The 5-HT receptors are present in the central and peripheral nervous system [13]. The antitussive property of opioids is mediated via activation of these receptors, which inhibits the cough [14,15]. Further, 5-HT receptor agonists play a role in antitussive therapy $[16,17]$ Therefore, we hypothesized that prior treatment with palonosetron increases the need for remifentanil in suppressing emergence cough. The study assessed the impact of palonosetron on the optimal effect-site concentration (Ce) of remifentanil to suppress emergence cough in females who underwent laparoscopic cholecystectomy.

\section{Materials and Methods}

\subsection{Patients}

This study was approved by the Ajou University Hospital Institutional Review Board (AJIRB-MED-THE-20-174, 9 July 2020) and registered at http:/ / ClinicalTrials.gov (NCT04563260, 24 September 2020). Following adequate information about this study, all patients provided written informed consent. Female patients with ASA physical status of I, II, or III aged between 19 and 85 years who underwent elective laparoscopic cholecystectomy were included from October 2020 to March 2021. Exclusion criteria were: body mass index $\geq 30 \mathrm{~kg} / \mathrm{m}^{2}$, uncontrolled hypertension, coronary disease, arrhythmia, acute and respiratory disease (asthma, chronic obstructive pulmonary disease, and upper airway infection within the last 2 weeks), prior use of an antitussive drug, and anticipated difficult airway.

\subsection{Anesthesia}

None of the patients was premedicated. In the operating room, patients received standard monitoring including pulse oximetry for oxygen saturation, electrocardiography, noninvasive blood pressure measurement, and bispectral index (BIS). A balanced anesthesia was implemented with sevoflurane and remifentanil (Ultian, Hanlim Pharm. Co., Ltd., Seoul, Korea). The TCI of remifentanil was set using a commercial TCI pump (Orchestra Base Primea, Fresinus Vial, Sevres, France) and was based on Minto's pharmacokinetics. Following pre-oxygenation, anesthesia was induced with propofol $2 \mathrm{mg} / \mathrm{kg}$ and remifentanil $3-5 \mathrm{ng} / \mathrm{mL}$ as Ce. After loss of consciousness, manual ventilation with sevoflurane and $100 \%$ oxygen was initiated, followed by rocuronium $1.0 \mathrm{mg} / \mathrm{kg}$ [18]. After confirming muscle relaxation with train-of-four counts of 0 , orotracheal intubation was conducted with a cuffed endotracheal tube (inner diameter, $7.0 \mathrm{~mm}$ ) using a videolaryngoscope. Cuff pressure was controlled to $20-25 \mathrm{mmHg}$ by a hand pressure gauge. Ventilation was mechanically initiated with a tidal volume of $6-8 \mathrm{~mL} / \mathrm{kg}$ and a $50 \%$ oxygen plus air, while maintaining $\mathrm{EtCO}_{2}$ at $35-40 \mathrm{mmHg}$. Anesthesia was continued using sevoflurane of 1 minimal alveolar concentration and remifentanil of $\leq 5 \mathrm{ng} / \mathrm{mL}$ as Ce to maintain a BIS level of hypnosis of 40-60 and mean arterial pressure (MAP) and heart rate (HR) values within $20 \%$ of the baseline values.

IV palonosetron $0.075 \mathrm{mg}$ was administered to the experimental group $10 \mathrm{~min}$ prior to the end of surgery, whereas the control group received the same volume of IV normal saline according to group assignments. IV acetaminophen $100 \mathrm{mg}$ was administered to both groups for postoperative analgesia. Simultaneously, the remifentanil Ce was set at the predetermined Ce. IV sugammadex $2 \mathrm{mg} / \mathrm{kg}$ was injected at the end of surgery to reverse the neuromuscular block. The secretions in the tracheal tube or the pharynx were suctioned. After confirming the train-of-four ratio $\geq 0.9$, sevoflurane was discontinued, and the fresh gas flow was increased to $5 \mathrm{~L} / \mathrm{min}$. Manual ventilation was started to maintain an $\mathrm{EtCO}_{2}$ of $40-45 \mathrm{mmHg}$ in accordance with the patient's spontaneous breath, followed by a verbal command to open the eyes without any stimulus. After eye opening upon verbal command and confirming adequate spontaneous ventilation, the tracheal tube cuff was deflated with a syringe, and the endotracheal tube was removed along its curve in the climax of the 
inspiration. Immediately, remifentanil was discontinued, and 100\% oxygen was supplied via a facial mask. If there was secretion in the mouth and pharynx, it was suctioned again. The patients were then transferred to the post-anesthesia care unit (PACU).

\subsection{Definition and Study Protocol}

Emergence cough was assessed after discontinuing sevoflurane until $3 \mathrm{~min}$ after extubation. The cough level was classified as: $0=$ no cough, $1=$ single (no sudden contraction of abdominal muscle), $2=$ more than one episode of nonsustained cough, and 3 = sustained and repetitive cough (H.Y.K. and N.Y.K.). Because level 1 had no clinical meaning, we deemed it as success. Two investigators were informed of the predetermined remifentanil Ce but blinded to the group assignment. Extubation time was defined as the duration from sevoflurane cessation until endotracheal extubation.

Patients were randomly assigned to either the control group or the palonosetron group using a computer-generated random table (http:/ / www.random.org, 10 July 2020) and the concealed envelopes method (J.E.K.). They were sequentially enrolled until completing at least 6 pairs of failure-success and 20 patients according to Dixon's up-and-down method. If one group reached 6 pairs of failure-success, then all the following patients were enrolled in the other group $[19,20]$. Dixon's sequential allocation design was adopted to determine the remifentanil Ce in each group. The first patient was started with $2.0 \mathrm{ng} / \mathrm{mL}$. The predetermined Ce of the next patient was determined by the cough response during emergence of the prior patient. If the patient did not cough or coughed at level 1 during emergence, it was defined as successful smooth emergence. The predetermined Ce of the next patient was decreased by a concentration of $0.5 \mathrm{ng} / \mathrm{mL}$ compared with the prior patient. If the patient coughed at levels 2 and 3, we defined them as fail, and the predetermined Ce of the next patient was increased by a concentration of $0.5 \mathrm{ng} / \mathrm{mL}$.

The number of intubation attempts was recorded, and the HR and MAP were recorded at 4 time-points: baseline (before induction), the end of surgery, after extubation, and at PACU. The end-tidal concentration of sevoflurane was recorded when opening the eyes on verbal command without stimuli. Respiratory complications such as hypoventilation (respiratory rate $<8$ breaths $/ \mathrm{min}$ ), laryngospasm, and desaturation (oxygen saturation $<95 \%$ ) were recorded. Immediately on arrival in the PACU, the sedation score using the Ramsay Sedation Scale (six levels: $1=$ anxious and agitated or restless or both; $6=$ no response) was assessed by the attending nurse. Nausea $(1=$ none, $2=$ mild, $3=$ moderate, and $4=$ severe $)$, vomiting, shivering, headache, and pain score using an 11-point numerical rating scale (NRS: $0=$ no pain, $10=$ worst pain) were also assessed. IV dexamethasone $5 \mathrm{mg}$ was administered for nausea $\geq 3$, and a fentanyl dose of $0.5 \mathrm{mcg} / \mathrm{kg}$ was administered in the event of NRS $\geq 5$. After $20 \mathrm{~min}$ of assessment, pain and nausea were re-evaluated. The patients were transferred to a ward when they reached a total modified Aldrete score of 8 , including respiratory score of 2 .

\subsection{Statistical Analysis}

The primary outcome was to estimate the $\mathrm{EC}_{50}$ and $\mathrm{EC}_{95}$ of remifentanil to suppress emergence cough depending on whether or not palonosetron was used. The $\mathrm{EC}_{50}$ was calculated as a mean value of remifentanil Ce and compared using the independent $t$-test. $\mathrm{EC}_{50}$ and $\mathrm{EC}_{95}$ were also calculated using the isotonic regression method in the basis of a pooled-adjacent-violators algorithm (PAVA), and $83 \%$ and $95 \%$ confidence intervals (CIs) were calculated through a boot strap method [19]. When $\mathrm{EC}_{50}$ and $\mathrm{EC}_{95}$ did not overlap at the $83 \%$ CIs and $95 \%$ CIs, they were considered as statistically significant differences. For sample size, patient enrollment was stopped in each group when completing at least 6 pairs of failure-success and 20 patients according to Dixon's up-and-down method [19].

Values were expressed as the mean \pm standard deviation (SD), the median (interquartile range), or the number of patients. Normality was determined using the Shapiro-Wilk test. Continuous variables were analyzed using Student's $t$-test or the Mann-Whitney test, depending on normality. Categorical variables were compared using the Chi-square test 
or Fisher's exact test. Repeated-measured variables were analyzed using a linear mixed model. A $p$ value of $<0.05$ was considered statistically significant. SAS (version 9.4, SAS Inc., Cary, NC, USA) and R package, version 4.0.5 (http:/ /www.R-project.org, 25 April 2021) was used for statistical analyses.

\section{Results}

\subsection{Study Population}

Three of the 48 enrolled patients refused to participate. Ultimately, 45 patients were randomized and included in the final analysis (Figure 1).

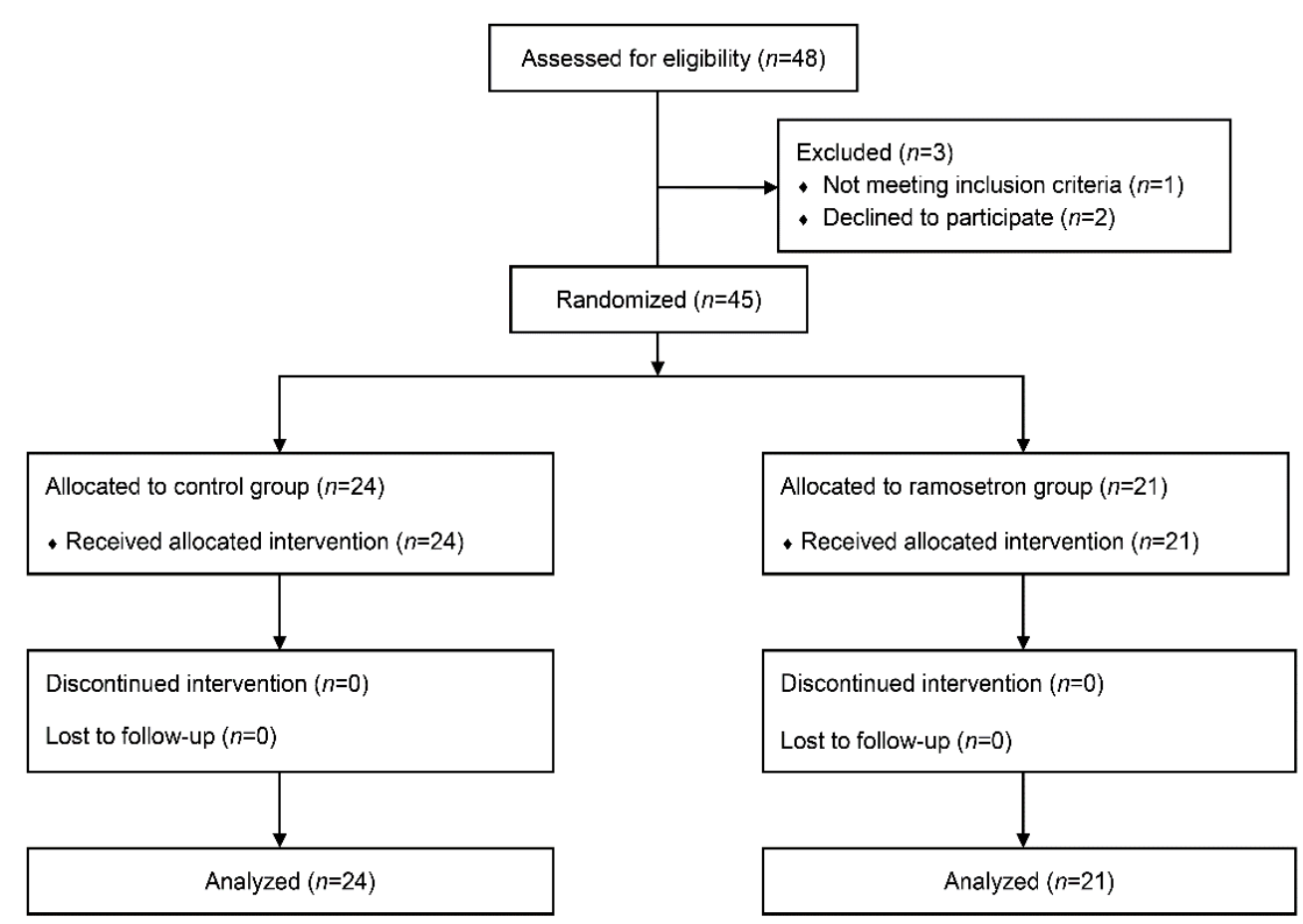

Figure 1. The CONSORT flow diagram of patients.

\subsection{Baseline Characteristics}

Demographic and intraoperative characteristics of patients did not differ between the two groups (Table 1). The MAP and HR were also comparable throughout perioperative period (Figure 2).

Table 1. Demographic and intraoperative characteristics of patients.

\begin{tabular}{lccc}
\hline & $\begin{array}{c}\text { Control } \\
(\boldsymbol{n}=\mathbf{2 4})\end{array}$ & $\begin{array}{c}\text { Palonosetron } \\
(\boldsymbol{n}=\mathbf{2 1})\end{array}$ & $p$-Value \\
\hline Age (years) & $48.0 \pm 13.2$ & $52.7 \pm 12.2$ & 0.222 \\
Height $(\mathrm{cm})$ & $159.3 \pm 6.1$ & $157.4 \pm 5.4$ & 0.282 \\
Weight $(\mathrm{kg})$ & $63.8 \pm 10.2$ & $59.1 \pm 9.7$ & 0.126 \\
ASA classification $1 / 2 / 3$ & $15 / 9 / 0$ & $12 / 8 / 1$ & 0.871 \\
Intubation attempts once/twice & $24 / 0$ & $21 / 0$ & 0.489 \\
Operation time (min) & $45(35-50)$ & $40(35-50)$ & 0.756 \\
Anesthesia time (min) & $75(65-80)$ & $75(65-80)$ & 0.881 \\
\hline
\end{tabular}

Values are expressed as the mean \pm standard deviation, median (interquartile range), or number. ASA, American Society of Anesthesiologists. 

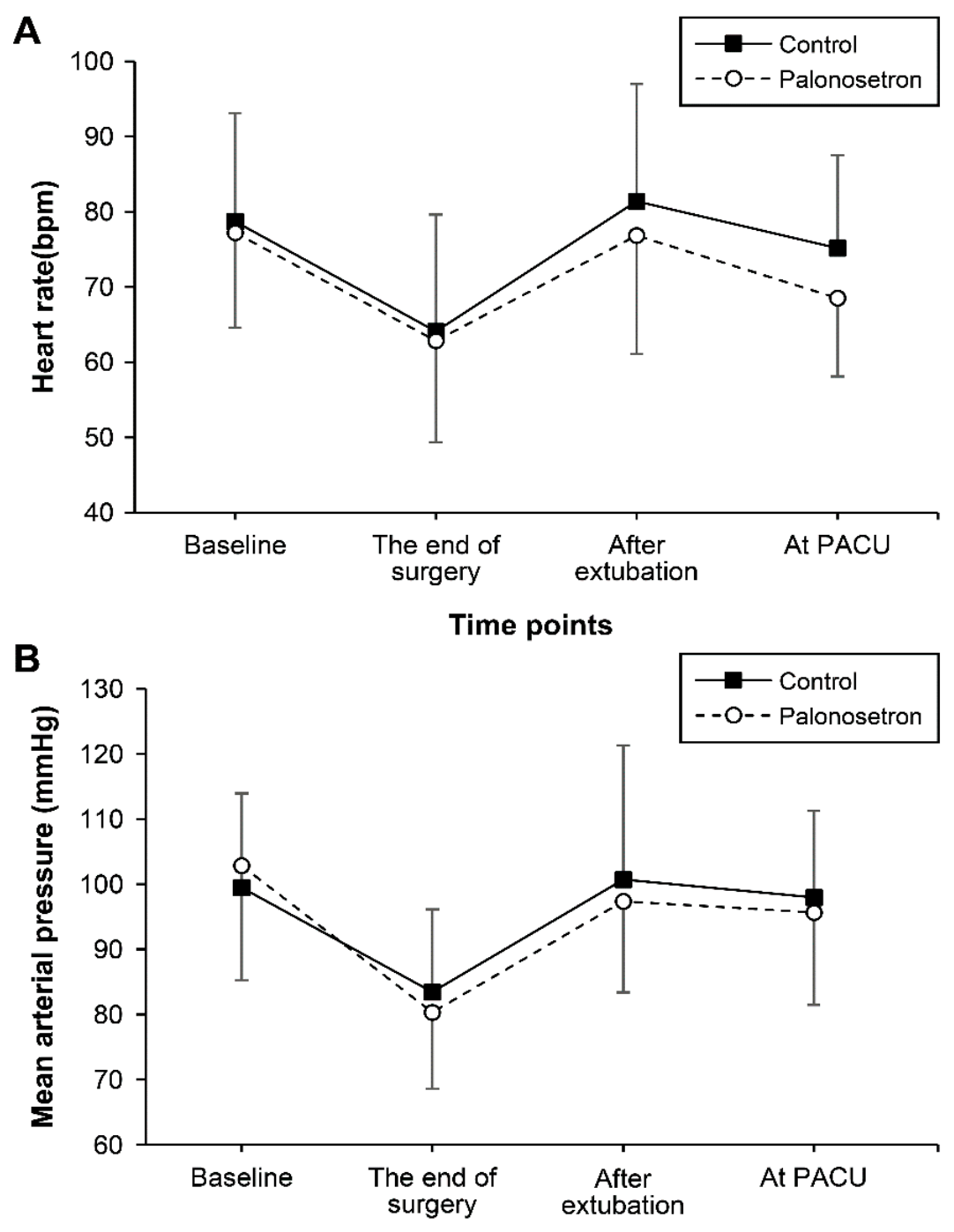

Time points

Figure 2. The (A) mean arterial pressure and (B) heart rate during the perioperative period. Data are expressed as the mean \pm standard deviation. PACU, post-anesthesia care unit. "Baseline" means before induction.

\subsection{Optimal Ce of Remifentanil}

The sequence of failures and successes on smooth emergence based on Dixon's method is showed in Figure 3, and an isotonic regression curve in the basis of PAVA response rate is presented in Figure 4. $\mathrm{EC}_{50}$ and $\mathrm{EC}_{95}$ values of remifentanil Ce for preventing emergence cough estimated with Dixon's method or isotonic regression are described in Table 2. Based on Dixon's method, $\mathrm{EC}_{50}$ of remifentanil Ce was $1.33 \pm 0.38 \mathrm{ng} / \mathrm{mL}$ in the control group, which was comparable to $1.42 \pm 0.75 \mathrm{ng} / \mathrm{mL}$ in the palonosetron group ( $p=0.813)$. Based on isotonic regression, $\mathrm{EC}_{50}$ of the remifentanil Ce was 1.17 (83\% CI, $0.86-1.43) \mathrm{ng} / \mathrm{mL}$ in the control group and $0.88(0.78-1.23) \mathrm{ng} / \mathrm{mL}$ in the palonosetron group. $\mathrm{EC}_{95}$ of the remifentanil Ce was $1.90(95 \% \mathrm{CI}, 1.45-1.96) \mathrm{ng} / \mathrm{mL}$ in the control group and 2.43 (1.94-2.47) $\mathrm{ng} / \mathrm{mL}$ in the palonosetron group. $\mathrm{EC}_{50}$ and $\mathrm{EC}_{95}$ values did not overlap, suggesting no significant difference in optimal remifentanil Ce between the two groups. 

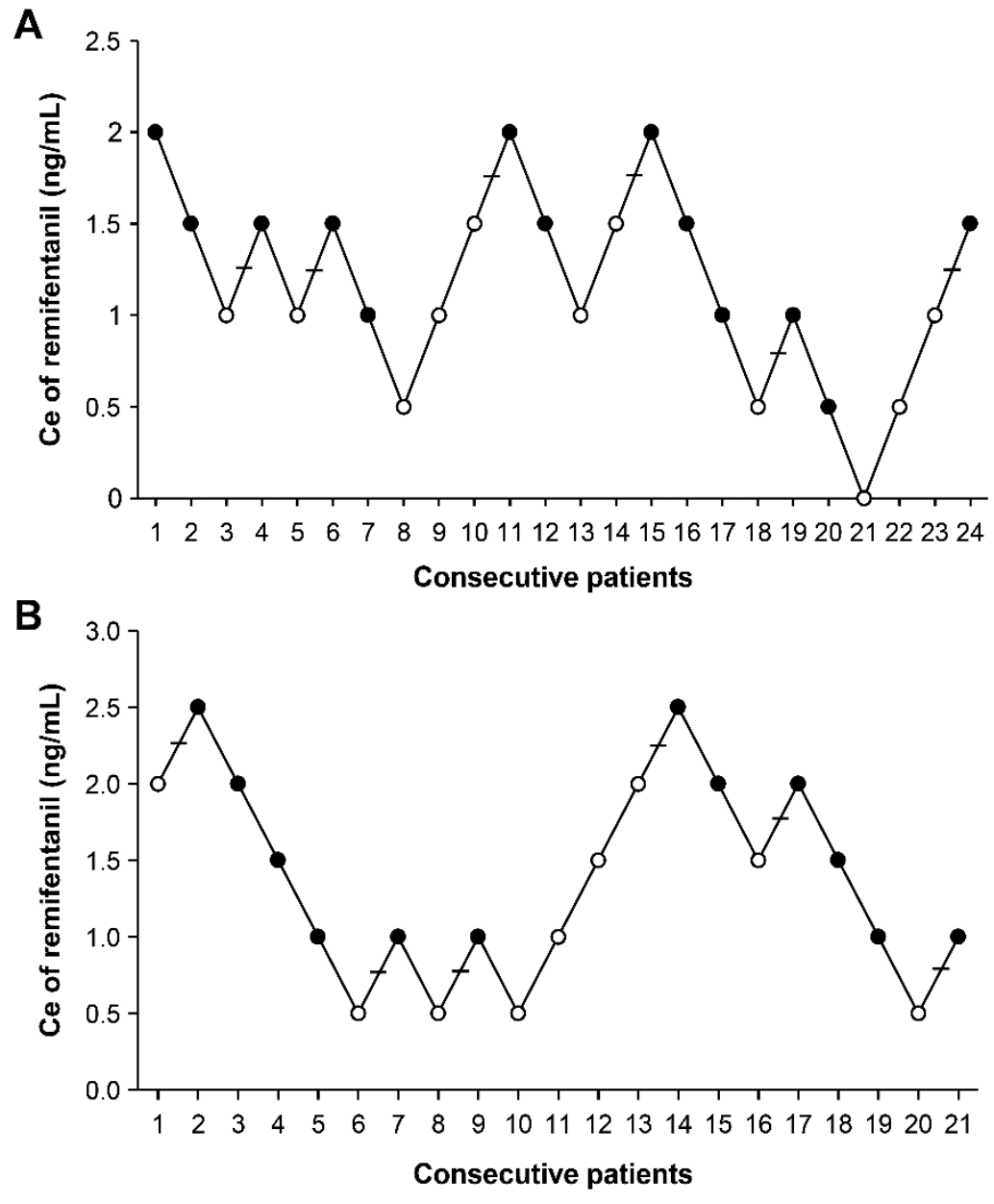

Figure 3. Sequences of effect-site concentration (Ce) of remifentanil to prevent emergence cough during extubation by Dixon's up-and-down methods. Horizontal bars represent crossover midpoints (i.e., failure to success). The mean $\mathrm{EC}_{50}$ of remifentanil Ce for suppressing emergence cough was calculated from cross-over pairs of success (closed circle) and failure (open circle) in (A) 24 patients in the control group and (B) 21 patients in the palonosetron group.

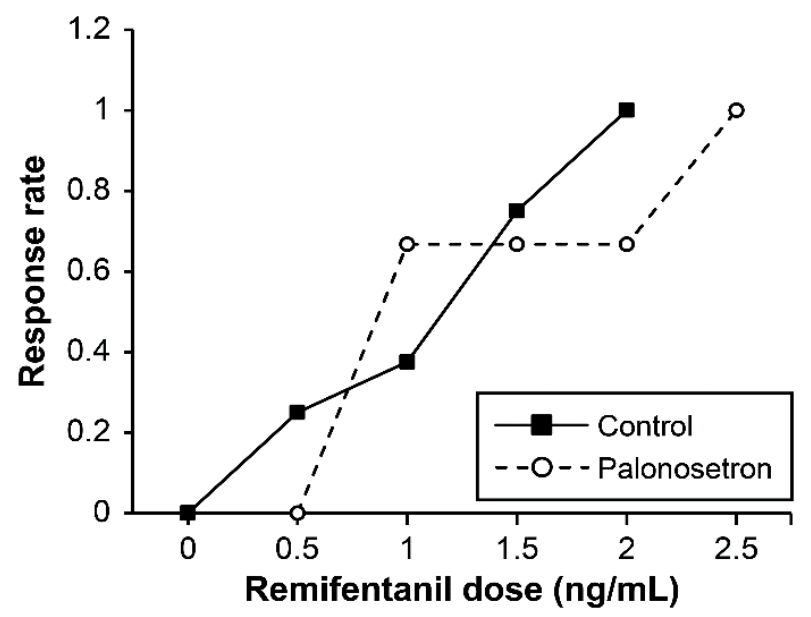

Figure 4. Pooled-adjacent-violators algorithm (PAVA) response rates in control (closed square) and palonosetron (open circle) groups of patients. The PAVA response rate means the ratio of the number of successful patients to the number of total patients at each remifentanil Ce in each group. 
Table 2. Optimal Ce of remifentanil for suppressing emergence cough.

\begin{tabular}{lccc}
\hline & $\begin{array}{c}\text { Control } \\
(\boldsymbol{n}=\mathbf{2 4})\end{array}$ & $\begin{array}{c}\text { Palonosetron } \\
(\boldsymbol{n}=\mathbf{2 1})\end{array}$ & $p$-Value \\
\hline $\begin{array}{l}\text { Dixon's method } \\
\quad C_{50} \text { of remifentanil Ce }(\mathrm{ng} / \mathrm{mL})\end{array}$ & $1.33 \pm 0.38$ & $1.42 \pm 0.75$ & 0.813 \\
$\quad \begin{array}{l}\text { Isotonic regression method } \\
\text { EC } 50 \text { of remifentanil Ce }(\mathrm{ng} / \mathrm{mL})\end{array}$ & $1.17(0.86-1.43)$ & $0.88(0.78-1.23)$ & \\
$\quad$ EC $_{95}$ of remifentanil Ce $(\mathrm{ng} / \mathrm{mL})$ & $1.90(1.45-1.96)$ & $2.43(1.94-2.47)$ & \\
\hline
\end{tabular}

$\mathrm{EC}_{50}$ expressed as the mean \pm standard deviation were determined by Dixon's method, and $\mathrm{EC}_{50}(83 \% \mathrm{CI})$ and $\mathrm{EC}_{95}(95 \% \mathrm{CI})$ were determined by the isotonic regression method. Ce, effect-site concentration; $\mathrm{CI}$, confidence interval.

\subsection{Emergence and Recovery Data}

The emergence and recovery data are presented in Table 3. During emergence from anesthesia, bradypnea was observed in three patients (remifentanil Ce: 0.5, 1.0, and $1.5 \mathrm{ng} / \mathrm{mL}$ ) in the control group and in one patient (remifentanil Ce, $1.0 \mathrm{ng} / \mathrm{mL}$ ) in the palonosetron group. However, these patients were restored to a normal respiratory pattern immediately via deep breathing using a facial mask. The sedation status of six levels showed significant difference between the two groups $(p=0.028)$ in the PACU; however, most patients showed sedation status within the range of awake levels (sedation levels: 1 , 2 , and 3) except for one patient in the control group $(p>0.999)$. In addition, no shivering occurred; however, three patients complained of a headache (two in the control group and one in the palonosetron group).

Table 3. Emergence and recovery data.

\begin{tabular}{lccc}
\hline & $\begin{array}{c}\text { Control } \\
(\boldsymbol{n}=\mathbf{2 4})\end{array}$ & $\begin{array}{c}\text { Palonosetron } \\
(\boldsymbol{n}=\mathbf{2 1})\end{array}$ & $p$-Value \\
\hline During emergence & & & \\
$\quad$ Extubation time (min) & $11.0 \pm 3.2$ & $11.1 \pm 3.5$ & 0.942 \\
$\quad$ EtSevo at eye opening (\%) & $0.25 \pm 0.1$ & $0.21 \pm 0.09$ & 0.155 \\
$\quad$ Respiratory complications & $3(13 \%)$ & $1(5 \%)$ & 0.611 \\
$\quad$ Bradypnea & 0 & 0 & \\
$\quad$ Laryngospasm & 0 & 0 & \\
$\quad$ Desaturation & & & \\
In the post-anesthesia care unit & $2 / 21 / 0 / 1 / 0 / 0$ & $0 / 17 / 4 / 0 / 0 / 0$ & 0.028 \\
Sedation score $1 / 2 / 3 / 4 / 5 / 6$ & $20 / 2 / 0 / 2$ & $18 / 3 / 0 / 0$ & 0.482 \\
Nausea $1 / 2 / 3 / 4$ & $1(4 \%)$ & 0 & $>0.999$ \\
Vomiting & $4.7 \pm 2.2$ & $5.2 \pm 1.6$ & 0.367 \\
Pain $(0-10)$ & $2(8 \%)$ & 0 & 0.491 \\
atients receiving antiemetics & $13(54 \%)$ & $16(76 \%)$ & 0.124 \\
Patients receiving analgesics & & 0.124 \\
\hline
\end{tabular}

Values are expressed as the mean \pm standard deviation or number (\%). EtSevo, end-tidal concentration of sevoflurane. Sedation score was recorded by Ramsay Sedation Scale range, 1-6.

\section{Discussion}

In this study, a balanced anesthesia using sevoflurane and remifentanil TCI was implemented in female patients to evaluate the impact of palonosetron on the optimal remifentanil Ce for smooth emergence. As a result, the $\mathrm{EC}_{50}$ and $\mathrm{EC}_{95}$ values of remifentanil for suppressing emergence cough at extubation were not significantly different between the two groups. Further, the emergence and recovery data were comparable.

Several possibilities may explain the lack of increase in remifentanil requirement for smooth emergence in the present study. First, the opioid system is known to interact functionally with the serotonergic system in the central nervous system. Multiple opioid receptors differentially modulate 5-HT efflux in the brain [14]. These opioid receptors mediate the hypotensive response induced by central $5-\mathrm{HT}_{3}$ receptor stimulation [21]. 
5- $\mathrm{HT}_{1}$ receptors modulate opioid release in the spinal cord, and its agonists prevent opioidinduced respiratory depression, analgesia, and sedation [22,23]. In addition, $5-\mathrm{HT}_{3}$ receptor antagonists such as ondansetron reduce opioid withdrawal behaviors [24]. Likewise, $5-\mathrm{HT}_{3}$ receptors mediate the vomiting reflex, processing of pain, cognition, and anxiety control [25]. However, few studies elucidate the role of $5-\mathrm{HT}_{3}$ receptors in the antitussive effect of opioids. Although tussigenic and antitussive effects of palonosetron on opioids in the central nervous system were not delineated by our study, it might not have a definitive impact on the results, because the human $5-\mathrm{HT}_{3}$ receptor is a target relatively less sensitive to remifentanil than to morphine [26].

Second, $5-\mathrm{HT}_{3}$ receptors exist in the respiratory tract. Airways receive a dense supply of sensory nerve fibers that originate mainly in the jugular and nodose vagal ganglia embryologically [27]. Although jugular ganglia do not express $5-\mathrm{HT}_{3}$ receptors, nodose ganglia expressing $5-\mathrm{HT}_{3}$ receptors are strongly activated by $5-\mathrm{HT}$ or a $5-\mathrm{HT}_{3}$ agonist [13]. Therefore, the injection of 5-HT or a $5-\mathrm{HT}_{3}$ agonist inhibits the cough response triggered by mechanical stimulation of trachea in animal studies $[13,28]$. In addition, $5-\mathrm{HT}$ has been shown to inhibit the cough reflex in humans at the peripheral site because 5-HT does not cross the blood-brain barrier [29]. Therefore, 5-HT receptor agonists were proposed as one of the novel antitussive treatments $[16,17]$. In this connection, we hypothesized that palonosetron, as a $5-\mathrm{HT}_{3}$ receptor antagonist, induces cough and increases the remifentanil $\mathrm{Ce}$. However, there was no increase of remifentanil Ce in the palonosetron group, presumably due to the critical role of jugular, rather than nodose, vagal ganglia in the induction and sensitization of cough [27].

Third, $5-\mathrm{HT}_{3}$ receptors are known to be expressed in the central and peripheral nervous system and integrate the processing of pain [25,30]. 5-HT activates presynaptic 5- $\mathrm{HT}_{3}$ receptors on spinal afferents, which transmit nociceptive input from the periphery to the brain, thereby increasing pain and reflex responses [31]. By contrast, the 5- $\mathrm{HT}_{3}$ receptor antagonist (ondansetron) prevents the development of chronic pain in rats [32]. As a nociceptive mechanism, the role of $5-\mathrm{HT}_{3}$ was established especially in formalin-induced nociception in mice [33]. The 5- $\mathrm{HT}_{3}$ receptor is involved in the release of pain mediators, such as substance $\mathrm{P}$ in the nerve, and a $5-\mathrm{HT}_{3}$ receptor antagonist affects substance P-mediated hyperalgesia [30]. In humans, treatment with 5- $\mathrm{HT}_{3}$ receptor antagonists alleviate chronic pain such as neuropathic pain, rheumatoid disease, migraine, and fibromyalgia $[30,34]$. In addition, granisetron, a specific $5-\mathrm{HT}_{3}$ receptor antagonist, increases the pain threshold in healthy males, indicating its potential local anesthetic role as an alternative to lidocaine [35]. Further, palonosetron pretreatment alleviates the pain induced by propofol as well as rocuronium injections, thereby reducing withdrawal movement during general anesthesia $[36,37]$. In view of the pain associated with endotracheal intubation, the antinociceptive effects of palonosetron during extubation in our study might neutralize its cough-inducing effect mentioned above.

In the present study involving females aged between 19 and 85 years and using acetaminophen for postoperative analgesia, $\mathrm{EC}_{50}$ of remifentanil Ce was $1.42 \pm 0.75 \mathrm{ng} / \mathrm{mL}$ after palonosetron administration compared with $1.33 \pm 0.38 \mathrm{ng} / \mathrm{mL}$ in the control group. However, in two previous studies conducted at the same institute, elderly females received ketorolac for postoperative analgesia, and $\mathrm{EC}_{50}$ values of remifentanil Ce after ramosetron administration were higher $(1.56 \pm 0.26 \mathrm{ng} / \mathrm{mL}$ and $2.08 \pm 0.47 \mathrm{ng} / \mathrm{mL})[38,39]$. This comparison may be reasonable because, except for these two variables (age and ketorolac), other conditions remained constant, including the inhalation agent (sevoflurane), endotracheal tube (cuffed, internal diameter of $7.0 \mathrm{~mm}$ ), sex (female), neuromuscular reversal drug (sugammadex), and surgical type (elective laparoscopic cholecystectomy). Further, the higher Ce of ramosetron may be underestimated because perioperative nonsteroidal antiinflammatory drugs (NSAIDs) such as ketorolac are more effective than acetaminophen in reducing the risk of PONV [40]. Possibly, ramosetron, the newer second-generation $5-\mathrm{HT}_{3}$ receptor antagonist, may be able to significantly increase remifentanil Ce for smooth 
extubation in contrast to palonosetron. Further studies are needed to shed additional light on these findings.

There are several limitations. First, adults and elderly females were included in the present study. However, age was considered because of the possible age-related differences in the cough reflex or the pharmacokinetics of opioid [41,42]. Second, cough severity might be a subjective interpretation on the patient's actions, thus posing the issue of interobserver variability and bias. Third, palonosetron was injected at the end of surgery, not at anesthetic induction. However, the injection timing of palonosetron is not yet settled, unlike that of dexamethasone or ramosetron [40]. Fourth, the incidence of PONV did not differ between the groups despite an ethical concern of no preventive treatment of PONV in the control group. Prophylactic IV acetaminophen known to reduce PONV might affect this nondifference [40]. Fifth, the postoperative pain score was high even for laparoscopic surgery. The use of long-acting opioids may be proper for laparoscopic cholecystectomy in clinical practice. Sixth, an experimental animal study may be needed to establish the role of $5-\mathrm{HT}_{3}$ receptor antagonists in the antitussive effects of opioid. Finally, the $\mathrm{EC}_{50}$ values showed different tendencies depending on Dixon's or isotonic regression methods, although there were no statistical differences. Further study with a large sample size may be needed to overcome a potential lack of power.

\section{Conclusions}

There was no difference in the optimal remifentanil Ce to suppress emergence cough between the palonosetron and the control groups. It may indicate no effect of palonosetron on antitussive activity of remifentanil. The remifentanil Ce to suppress emergence cough may not be adjusted in clinical practice when used in female patients previously treated with palonosetron.

Author Contributions: Conceptualization, H.-Y.K. and J.-E.K.; methodology, H.-Y.K.; validation, H.-Y.G., H.-Y.K., and J.-E.K.: formal analysis, H.-S.L.; investigation, H.-Y.K. and N.-Y.K.; resources, J.-E.K.; data curation, H.-Y.G.; writing_-original draft preparation, H.-Y.G.; writing-review and editing, H.-Y.K. and J.-E.K.; visualization, H.-Y.G.; supervision, H.-Y.K. and J.-E.K. All authors have read and agreed to the published version of the manuscript.

Funding: This research received no external funding.

Institutional Review Board Statement: The study was conducted according to the guidelines of the Declaration of Helsinki and approved by the Institutional Review Board of Ajou University Hospital (No. AJIRB-MED-THE-20-174).

Informed Consent Statement: Written informed consent was obtained from all patients involved in the study.

Data Availability Statement: The datasets used and analyzed during the current study are available from the corresponding author upon reasonable request.

Conflicts of Interest: The authors declare no conflict of interests.

\section{References}

1. Kim, E.S.; Bishop, M.J. Cough during emergence from isoflurane anesthesia. Anesth. Analg. 1998, 87, 1170-1174. [CrossRef]

2. Canning, B.J.; Chang, A.B.; Bolser, D.C.; Smith, J.A.; Mazzone, S.B.; McGarvey, L. Anatomy and neurophysiology of cough: CHEST Guideline and Expert Panel report. Chest 2014, 146, 1633-1648. [CrossRef]

3. Rosato, L.; Avenia, N.; Bernante, P.; De Palma, M.; Gulino, G.; Nasi, P.G.; Pelizzo, M.R.; Pezzullo, L. Complications of thyroid surgery: Analysis of a multicentric study on 14,934 patients operated on in Italy over 5 years. World J. Surg. 2004, 28, 271-276. [CrossRef]

4. Drummond, J.C.; Patel, P.M.; Lemkuil, B.P. Anesthesia for neurologic surgery. In Miller's Anesthesia, 8th ed.; Miller, R.D., Eriksson, L.I., Fleisher, L.A., Wiener-Kronish, J.P., Cohen, N.H., Young, W.L., Eds.; Elsevier/Saunders: Philadelphia, PA, USA, 2015; pp. 2158-2199.

5. Von Ungern-Sternberg, B.S.; Davies, K.; Hegarty, M.; Erb, T.O.; Habre, W. The effect of deep vs. awake extubation on respiratory complications in high-risk children undergoing adenotonsillectomy: A randomised controlled trial. Eur. J. Anaesthesiol. 2013, 30, 529-536. [CrossRef] [PubMed] 
6. Tung, A.; Fergusson, N.A.; Ng, N.; Hu, V.; Dormuth, C.; Griesdale, D.G.E. Pharmacological methods for reducing coughing on emergence from elective surgery after general anesthesia with endotracheal intubation: Protocol for a systematic review of common medications and network meta-analysis. Syst. Rev. 2019, 8, 32. [CrossRef] [PubMed]

7. Safavi, M.; Honarmand, A.; Khazaei, M. The effects of propofol, ketamine and combination of them in prevention of coughing and laryngospasm in patients awakening from general anesthesia: A randomized, placebo-controlled, double blind clinical trial. Adv. Biomed. Res. 2016, 5, 64. [PubMed]

8. Mandel, J.E. Considerations for the use of short-acting opioids in general anesthesia. J. Clin. Anesth. 2014, 26, S1-S7. [CrossRef]

9. Tung, A.; Fergusson, N.A.; Ng, N.; Hu, V.; Dormuth, C.; Griesdale, D.E.G. Medications to reduce emergence coughing after general anaesthesia with tracheal intubation: A systematic review and network meta-analysis. Br. J. Anaesth. 2020, 124, 480-495. [CrossRef]

10. Apfel, C.C.; Korttila, K.; Abdalla, M.; Kerger, H.; Turan, A.; Vedder, I.; Zernak, C.; Danner, K.; Jokela, R.; Pocock, S.J.; et al. A factorial trial of six interventions for the prevention of postoperative nausea and vomiting. N. Engl. J. Med. 2004, 350, 2441-2451. [CrossRef] [PubMed]

11. Stoltz, R.; Cyong, J.C.; Shah, A.; Parisi, S. Pharmacokinetic and safety evaluation of palonosetron, a 5-hydroxytryptamine-3 receptor antagonist, in U.S. and Japanese healthy subjects. J. Clin. Pharmacol. 2004, 44, 520-531. [CrossRef] [PubMed]

12. Reddy, G.S.; Manjusruthi, B.; Jyothsna, G. Postoperative Nausea and Vomiting Prophylaxis: A Comparative Study of Ramosetron and Palonosetron in Patients Undergoing Laparoscopic Cholecystectomy-A Prospective Randomized Trial. Anesth. Essays Res. 2019, 13, 68-72. [PubMed]

13. Chou, Y.L.; Mori, N.; Canning, B.J. Opposing effects of bronchopulmonary C-fiber subtypes on cough in guinea pigs. Am. J. Physiol. Regul. Integr. Comp. Physiol. 2018, 314, R489-R498. [CrossRef] [PubMed]

14. Tao, R.; Auerbach, S.B. Opioid receptor subtypes differentially modulate serotonin efflux in the rat central nervous system. $J$. Pharmacol. Exp. Ther. 2002, 303, 549-556. [CrossRef] [PubMed]

15. Driessen, A.K.; Farrell, M.J.; Mazzone, S.B.; McGovern, A.E. Multiple neural circuits mediating airway sensations: Recent advances in the neurobiology of the urge-to-cough. Respir. Physiol. Neurobiol. 2016, 226, 115-120. [CrossRef]

16. Dicpinigaitis, P.V. Potential future therapies for the management of cough: ACCP evidence-based clinical practice guidelines. Chest 2006, 129, 284S-286S. [CrossRef] [PubMed]

17. Barnes, P.J. The problem of cough and development of novel antitussives. Pulm. Pharmacol. Ther. 2007, 20, 416-422. [CrossRef]

18. Martini, C.H.; Boon, M.; Bevers, R.F.; Aarts, L.P.; Dahan, A. Evaluation of surgical conditions during laparoscopic surgery in patients with moderate vs deep neuromuscular block. Br. J. Anaesth. 2014, 112, 498-505. [CrossRef]

19. Pace, N.L.; Stylianou, M.P. Advances in and limitations of up-and-down methodology: A précis of clinical use, study design, and dose estimation in anesthesia research. Anesthesiology 2007, 107, 144-152. [CrossRef]

20. Stylianou, M.; Flournoy, N. Dose finding using the biased coin up-and-down design and isotonic regression. Biometrics 2002, 58, 171-177. [CrossRef]

21. Fregoneze, J.B.; Oliveira, E.F.; Ribeiro, V.F.; Ferreira, H.S.; De Castro, E.S.E. Multiple opioid receptors mediate the hypotensive response induced by central 5-HT(3) receptor stimulation. Neuropeptides 2011, 45, 219-227. [CrossRef]

22. Song, B.; Chen, W.; Marvizón, J.C. Inhibition of opioid release in the rat spinal cord by serotonin 5-HT(1A) receptors. Brain Res. 2007, 1158, 57-62. [CrossRef] [PubMed]

23. Ren, J.; Ding, X.; Greer, J.J. 5-HT1A receptor agonist Befiradol reduces fentanyl-induced respiratory depression, analgesia, and sedation in rats. Anesthesiology 2015, 122, 424-434. [CrossRef]

24. Chu, L.F.; Liang, D.Y.; Li, X.; Sahbaie, P.; D’Arcy, N.; Liao, G.; Peltz, G.; David Clark, J. From mouse to man: The 5-HT3 receptor modulates physical dependence on opioid narcotics. Pharm. Genom. 2009, 19, 193-205. [CrossRef] [PubMed]

25. Walstab, J.; Rappold, G.; Niesler, B. 5-HT(3) receptors: Role in disease and target of drugs. Pharmacol. Ther. 2010, 128, 146-169. [CrossRef]

26. Wittmann, M.; Schaaf, T.; Peters, I.; Wirz, S.; Urban, B.W.; Barann, M. The effects of fentanyl-like opioids and hydromorphone on human 5-HT3A receptors. Anesth. Analg. 2008, 107, 107-112. [CrossRef] [PubMed]

27. Moe, A.A.K.; McGovern, A.E.; Mazzone, S.B. Jugular vagal ganglia neurons and airway nociception: A target for treating chronic cough. Int. J. Biochem. Cell Biol. 2021, 135, 105981. [CrossRef] [PubMed]

28. Mazzone, S.B.; Undem, B.J. Vagal Afferent Innervation of the Airways in Health and Disease. Physiol. Rev. 2016, 96, 975-1024. [CrossRef]

29. Stone, R.A.; Worsdell, Y.M.; Fuller, R.W.; Barnes, P.J. Effects of 5-hydroxytryptamine and 5-hydroxytryptophan infusion on the human cough reflex. J. Appl. Physiol. (1985) 1993, 74, 396-401. [CrossRef] [PubMed]

30. Faerber, L.; Drechsler, S.; Ladenburger, S.; Gschaidmeier, H.; Fischer, W. The neuronal 5-HT3 receptor network after 20 years of research-evolving concepts in management of pain and inflammation. Eur. J. Pharmacol. 2007, 560, 1-8. [CrossRef]

31. Suzuki, R.; Morcuende, S.; Webber, M.; Hunt, S.P.; Dickenson, A.H. Superficial NK1-expressing neurons control spinal excitability through activation of descending pathways. Nat. Neurosci. 2002, 5, 1319-1326. [CrossRef]

32. Suzuki, R.; Rahman, W.; Hunt, S.P.; Dickenson, A.H. Descending facilitatory control of mechanically evoked responses is enhanced in deep dorsal horn neurones following peripheral nerve injury. Brain Res. 2004, 1019, 68-76. [CrossRef] 
33. Kayser, V.; Elfassi, I.E.; Aubel, B.; Melfort, M.; Julius, D.; Gingrich, J.A.; Hamon, M.; Bourgoin, S. Mechanical, thermal and formalin-induced nociception is differentially altered in 5-HT1A-/-, 5-HT1B-/-, 5-HT2A-/-, 5-HT3A-/- and 5-HTT-/- knock-out male mice. Pain 2007, 130, 235-248. [CrossRef]

34. McCleane, G.J.; Suzuki, R.; Dickenson, A.H. Does a single intravenous injection of the 5HT3 receptor antagonist ondansetron have an analgesic effect in neuropathic pain? A double-blinded, placebo-controlled cross-over study. Anesth. Analg. 2003, 97, 1474-1478. [CrossRef]

35. Ernberg, M.; Wieslander Fältmars, A.; Hajizadeh Kopayeh, M.; Arzt Wallén, S.; Cankalp, T.; Christidis, N. The Effect of Granisetron on Sensory Detection and Pain Thresholds in Facial Skin of Healthy Young Males. Front. Neurol. 2020, 11, 237. [CrossRef] [PubMed]

36. Cho, K.; Lee, S.H.; Lee, W.; Chu, B.K.; Kim, M.H.; Lim, S.H.; Lee, K.M. Effect of pretreatment with palonosetron on withdrawal movement associated with rocuronium injection. Korean J. Anesthesiol. 2014, 66, 23-27. [CrossRef] [PubMed]

37. Ryu, H.B.; Kim, S.J. Analgesic effects of palonosetron in the intravenous propofol injection. Korean J. Anesthesiol. 2014, 66, 99-104. [CrossRef]

38. Lee, S.Y.; Jeong, Y.Y.; Lee, B.H.; Kim, J.E. Sex-related differences in effect-site concentration of remifentanil for preventing anesthetic emergence cough in elderly patients. Clin. Interv. Aging 2018, 13, 81-89. [CrossRef] [PubMed]

39. Kim, H.Y.; Moon, Y.R.; Seok, S.; Kim, B.; Kim, J.E.; Lee, S.Y. Comparison of sevoflurane and desflurane on effect-site concentration of remifentanil for preventing anesthetic emergence cough in elderly female patients undergoing laparoscopic cholecystectomy. Clin. Interv. Aging 2018, 13, 1769-1777. [CrossRef]

40. Gan, T.J.; Belani, K.G.; Bergese, S.; Chung, F.; Diemunsch, P.; Habib, A.S.; Jin, Z.; Kovac, A.L.; Meyer, T.A.; Urman, R.D.; et al. Fourth Consensus Guidelines for the Management of Postoperative Nausea and Vomiting. Anesth. Analg. 2020, 131, 411-448. [CrossRef] [PubMed]

41. Ebihara, S.; Ebihara, T.; Kohzuki, M. Effect of aging on cough and swallowing reflexes: Implications for preventing aspiration pneumonia. Lung 2012, 190, 29-33. [CrossRef]

42. Minto, C.F.; Schnider, T.W.; Shafer, S.L. Pharmacokinetics and pharmacodynamics of remifentanil. II. Model application. Anesthesiology 1997, 86, 24-33. [CrossRef] [PubMed] 